\title{
A comparison of prevalence of unethical tendering practices at national and subnational levels in Nigeria
}

\begin{tabular}{|c|c|}
\hline \multicolumn{2}{|c|}{$\begin{array}{l}\text { Authors: } \\
\text { Chukwuemeka P. Ogbu }{ }^{1} \\
\text { Christian F. Asuquo }{ }^{2}\end{array}$} \\
\hline \multicolumn{2}{|c|}{$\begin{array}{l}\text { Affiliations: } \\
{ }^{1} \text { Department of Quantity } \\
\text { Surveying, University of } \\
\text { Benin, Nigeria }\end{array}$} \\
\hline \multicolumn{2}{|c|}{$\begin{array}{l}{ }^{2} \text { Department of Quantity } \\
\text { Surveying, University of Uyo, } \\
\text { Nigeria }\end{array}$} \\
\hline \multicolumn{2}{|c|}{$\begin{array}{l}\text { Corresponding author: } \\
\text { Chukwuemeka Ogbu, } \\
\text { chukwuemeka.ogbu@ } \\
\text { uniben.edu }\end{array}$} \\
\hline \multicolumn{2}{|c|}{$\begin{array}{l}\text { Received: } 19 \text { Dec. } 2017 \\
\text { Accepted: } 08 \text { Apr. } 2018 \\
\text { Published: } 14 \text { June } 2018\end{array}$} \\
\hline \multicolumn{2}{|c|}{$\begin{array}{l}\text { How to cite this article: } \\
\text { Ogbu, C.P. \& Asuquo, C.F., } \\
\text { 2018, 'A comparison of } \\
\text { prevalence of unethical } \\
\text { tendering practices at } \\
\text { national and subnational } \\
\text { levels in Nigeria', Africa's } \\
\text { Public Service Delivery and } \\
\text { Performance Review 6(1), } \\
\text { a217. https://doi.org/ } \\
\text { 10.4102/apsdpr.v6i1.217 }\end{array}$} \\
\hline \multicolumn{2}{|c|}{$\begin{array}{l}\text { Copyright: } \\
\text { ( ) 2018. The Authors. } \\
\text { Licensee: AOSIS. This wo } \\
\text { is licensed under the } \\
\text { Creative Commons } \\
\text { Attribution License. }\end{array}$} \\
\hline \multicolumn{2}{|l|}{ Read online: } \\
\hline 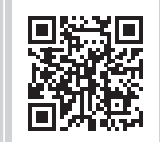 & $\begin{array}{l}\text { Scan this QR } \\
\text { code with your } \\
\text { smart phone or } \\
\text { mobile device } \\
\text { to read online. }\end{array}$ \\
\hline
\end{tabular}

Nigeria has recently renewed efforts towards stamping out corruption in every area of its national life. Given that construction procurement is particularly prone to corrupt practices, this study investigated the prevalence of unethical tendering practices in the Nigerian public sector. In particular, a comparison to bare the similarities or differences in the prevalence of unethical tendering practices at national and subnational levels is scarcely available in literature. This study's objective was to determine and compare the prevalence of unethical tendering practices at the national and subnational levels in Nigeria. The data analysis was based on 120 acceptably filled questionnaires obtained from contractor, client and consultant organisations previously involved in public sector projects. The unethical tendering practices were analysed using prevalence indices and Mann-Whitney $U$ tests. Findings include that the three most prevalent unethical tendering practices are contractor-based, namely: (1) competitors offer bribes to gain access to confidential tendering information (C1); (2) competitors overstate their capacity, experience and qualifications to secure construction contracts (C2); (3) the same owner(s) use different firms to tender for the same project (C3), in descending order of prevalence. No significant difference exists between unethical tendering practices in federal and state government projects. The findings of the study will help the Nigerian government and other stakeholders to better understand unethical practices at the tender stage of construction procurement in the public sector and to evolve better strategies for dealing with them. The study contributes to existing knowledge by separately identifying the prevalent unethical tendering practices in the Nigerian context and comparing unethical tendering practices at national and subnational levels within a country.

\section{Introduction}

Unethical practices in the construction industry are a global phenomenon. Justifiably, it has attracted the attention of researchers from different countries of the world (Abdul-Rahman, Wang \& Yap 2010; Vee \& Skitmore 2003). Available research in this area points to dynamism in the nature of the problem and to its context dependences (Suen, Cheung \& Mondejar 2007). Le et al. (2014) rightly observed that unethical practices are present in both developing and developed economies. Nevertheless, construction-related research findings from developing countries are frequently dissimilar from those from the developed world, which may be connected with the poor institutional frameworks, lack of innovation and administrative lapses in such countries (Ofori 2000 , 2007). Added to this, especially in the field of ethics, differing organisations, governments, cultural practices and ethical philosophies entail that research must be context-specific (Somers 2001; Spicer, Dunfee \& Bailey 2004; Suen et al. 2007). Bowen, Edwards and Cattell (2012) developed four thematic issues in their study of construction industry corruption in South Africa. These include involvement in corruption, forms of corruption, factors that may give rise to corrupt activities and means of combating corruption. The outcome of the investigation of any of these themes will depend on the systems and institutions in which the corruption is embedded. In Nigeria, however, it is also important to compare the prevalence of corruption between federal and state governments. Previous studies in the context of this research (notably Alutu 2007; Ameh \& Odusami 2010a, 2010b) did not concentrate on this area.

Nigeria has for a long time been regarded as very corrupt. This has been reflected by several poor rankings by Transparency International's Corruption Perception Index (CPI). Of the three biggest economies in Africa, namely, Nigeria, Egypt and South Africa, Nigeria is the most corrupt. Nigeria is also more corrupt than neighbouring Ghana where Ameyaw et al. (2017) and Bowen et al. (2007a), respectively, found evidences of widespread corruption (see Figures 1 and 2). Whereas corruption in the country is not confined to any particular industry, studies have shown 


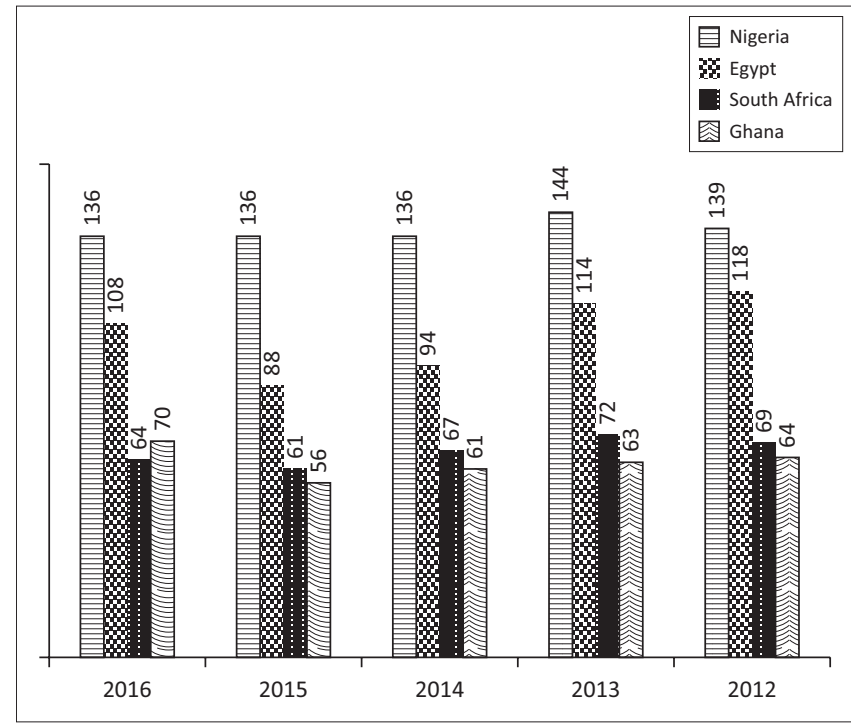

Source: Transparency International, 2016, Corruption perception index, viewed 26 August 2017, from https://www.transparency.org/research/cpi

FIGURE 1: Corruption index rankings.

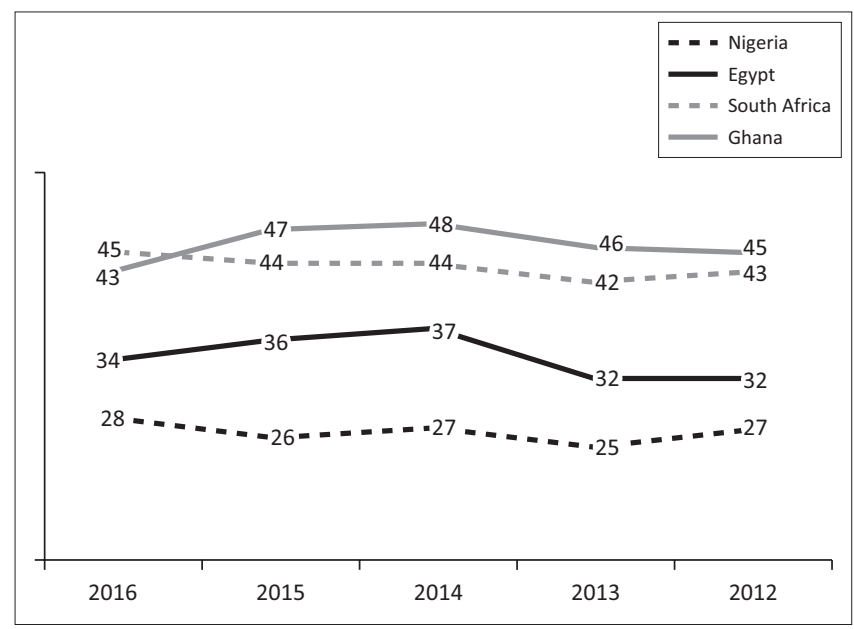

Source: Transparency International, 2016, Corruption perception index, viewed 26 Augus 2017, from https://www.transparency.org/research/cpi

FIGURE 2: Corruption index scores.

that corruption is frequently associated with construction contracts (Al-sweity 2013; Alutu 2007; Ameh \& Odusami 2010a). Construction contracts usually involve huge sums of money, making them attractive to corrupt persons. In such contracts, unethical practices at other stages of procurement subsequent to the tender stage can be better handled if unethical tendering practices were prevented.

Extant studies tend to focus on national governments or whole countries, without investigating the relative prevalence of the phenomenon between national and subnational governments. Based on the relativist theory of ethics, where there are differing ethical and political environments between these two levels of government, such studies fail to give any meaningful insight into variations in ethical behaviour within a nation.

Previous studies have found that unethical practices in construction procurement are higher at the tender stage (Adnan et al. 2012; Al-sweity 2013; Bowen et al. 2007a;
Chartered Institute of Building 2013). While it is known that unethical practices are endemic in the Nigerian construction industry (Al-sweity 2013; Ameh \& Odusami 2010a), studies focusing primarily on the prevalence of unethical tendering practices in Nigeria are hard to come by. Likewise, the stage of tendering that is most vulnerable to unethical practices by procurement officers is yet to be identified. The salience of these last two issues is that it is doubtful that existing procurement laws (notably, the Public Procurement Act [PPA] 2007) in Nigeria were made specifically to address empirically established unethical conducts at the different stages of tendering in the public sector.

The legal and institutional frameworks for public procurement in Nigeria are progressively being tightened against corruption and other unethical practices. A few examples of actions taken in this regard include the establishment of antigraft agencies (e.g. the Economic and Financial Crimes Commission established in 2002; and the Independent Corrupt Practices Commission established in 2000) and procurement management and budget control institutions such as the Budget Monitoring and Price Intelligence Unit (BMPIU) established in 2002, which later became the Bureau of Public Procurement (BPP) in 2007. The laws establishing these institutions have implications for unethical construction industry tendering practices as well. Specifically, the PPA (2007) (which established the BPP) was enacted to ensure probity, accountability and transparency in the federal government's procurement arrangements at all levels (Federal Republic of Nigeria [FRN] 2007a). Since its enactment at the federal level, similar laws have been enacted by some states (Agbor 2012; Usman 2014). Alutu (2007), Ameh and Odusami (2010a) and Ameh and Odusami (2010b) were written when these policies and laws were fresh; thus, the studies could hardly capture the effects of their full implementation. Secondly, they made no distinctions between corruption at the state and federal government project levels. Corruption is still known to exist in the Nigerian construction industry (Aniekwu, Anthony \& Kehinde 2015), but because there are differing procurement laws, it will be necessary to determine the level at which it is more prevalent in the country.

With the huge amount of money usually associated with construction projects, attempts to unfairly and/or illegally influence the outcome of tendering have severe negative impacts on construction costs. Through unethical practices, financial resources allocated for infrastructure development are often frittered away, leading to increased construction costs resulting from inefficiency (Al-sweity 2013). In European countries, tendering corruption costs up to $20 \%$ of the project price, while it costs up to $33 \%$ in Japan (Zhang, Yun \& Skitmore 2017). Similar estimates of the cost of corruption are not generally known to exist for Nigeria. Despite this, the BMPIU claimed to have saved Nigeria the sum of N140 billion (about \$391 million) between the time of its establishment in 2002 and October 2004 (Aduda 2007). Usman (2014) reported that the BPP saved the country the sum of N588bn (about \$1.65bn) from fiscal year 2009 to fiscal year 2013. This scenario confirms 
the findings of the Organisation for Economic Co-operation and Development (2014) that procurement-related bribery, of which tendering is an important aspect, accounts for $57 \%$ of bribes in some countries. With a view to strengthening strategies for curbing tendering corruption, the objectives of this paper are (1) to evaluate unethical tendering practices in the Nigerian public sector; (2) to ascertain the difference in the prevalence of unethical tendering practices at the federal and state government levels in Nigeria; and (3) to ascertain the difference in the prevalence of unethical tendering practices at the invitation to tender and the tender evaluation and award stages.

\section{Literature review}

Globally, the construction industry plays a vital role in the economy of a nation regardless of the level of development of such an economy. It contributes to employment generation and to a nation's gross fixed capital formation. In the Nigerian case, the National Bureau of Statistics (NBS) (2016a) showed that the construction sector contributed an average of $2.5 \%$ to the total jobs created in the formal sector between Q4 2015 and Q1 2016. In Q1 2016, the industry contributed 3.99\% to the nominal GDP of Nigeria (NBS 2016b). Aigbavboa, Oke and Tyali (2016) blamed unethical practices for the Nigerian construction industry's inability to consistently and effectively contribute to the growth of the economy.

\section{Professional ethics}

In Ray, Hornibrook and Skitmore's view, basically, ethics concerns the rightness or wrongness of intentions, the means of carrying out the intentions and the ends those intentions pursue (1999). Bayles (1989) defined professional ethics as a system of norms that control both the morality and behaviour of professionals in their day-to-day practice. In the view of Le et al. (2014), professional ethics is a set of moral principles that govern the conduct of professionals. However, in a construction contract, clients, contractors and consultants (professionals) can be guilty of unethical practices. For example, Bowen, Pearl and Akintoye (2007b) found that both professionals and clients were guilty of divulging confidential project information to third parties. Oliver, London and Everingham (2006) argued that the term 'profession' includes clients and the government. Clients and the government have responsibilities to be ethical in all conducts related to the construction industry. For this study, tendering ethics concerns adherence to moral, legal and regulatory procedures during tendering by all participants and stakeholders in the process. Two moral perspectives are discernible for settling moral conflicts. They are the relativist and absolutist standpoints. The relativists posit that moral conflicts cannot be resolved by any constant or generally agreed method of reasoning (DeCew 1990). Simply, it means that ethical judgements are context- and agent-dependent, and so an action can be adjudged moral or immoral at the same time, depending on who is involved, the group to which he or she belongs or who the appraiser is (Lyons 1976). Contrariwise, the absolutists contend that, 'a morally competent and clearheaded person need not encounter irresoluble moral dilemmas'
(DeCew 1990:29). It 'dictates that an omni-present set of standards should apply universally, being equally valid in all places and times' (Gael 2010:456). Given the differing levels of government in Nigeria (federal and states) and the difference in procurement laws, arguably, tendering ethical dilemmas should be settled from the relativist perspective. Whether the differing procurement laws make tendering moral judgements context-determined (Onuigbo \& Eme 2015) will be investigated by this study.

\section{Corruption and unethical practices in Nigeria's public sector}

Tendering is the process of selecting a suitable contractor for a construction project, either by negotiation or by competition, and it ultimately leads to the award of a contract (Chinyio 2011). It is the most widely-used method of awarding building and civil engineering work in the public sector (Zarkada-Fraser \& Skitmore 1998). Although the approach to tendering can be by competition or by negotiation, in the Nigerian public sector, competition is the accepted approach, except in very exceptional cases (e.g. in the procurement of military wares) (FRN 2007a).

In 1999, Transparency International ranked Nigeria as the second most corrupt nation in the world (Transparency International 2016). With the coming on board of the new civilian administration of President Olusegun Obasanjo in the same year, Nigeria began a renewed effort towards stamping out corruption in all of its ramifications. Prior to 2007, the legal aspects of procurement corruption relied mainly on the provisions of the general criminal laws of Nigeria for their enforcement. From 2002, the Economic and Financial Crimes Commission was mainly saddled with this role of enforcement of financial laws. In 2007, the coming on board of the PPA 2007 as well as the BPP signalled a major effort to shore up the ethical conduct of public procurement processes in the country. In the short run, the PPA 2007 appeared to yield a positive result. For instance, Nigeria's CPI rank improved from 142 out of 163 in 2006 (a year before the Act) to 121 out of 180 in 2008, a year after the Act was signed into law (Transparency International 2016). Similarly, a study by Adeyinka et al. (2013) indicated that Nigerian construction professionals satisfactorily complied with ethical standards.

On the contrary, other studies seem to suggest that after the short run recovery from corruption, the country slipped back to its old ways of corruption, reaching 143 out of 183 and 144 out of 177 in the years 2011 and 2013, respectively (Transparency International 2016). Jibrin, Ejura and Nwaorgu (2014) and Aigbavboa et al. (2016) noted that most public procurement activities in Nigeria suffer from lack of open competition and transparency, as well as differing levels of corruption despite the existence of various anti-graft institutions, laws and codes of ethics guiding stakeholders' practices. Some of the respondents to Aduda's (2007) study pointed out that when the BMPIU began, it was a laudable idea, but it later appeared to fall into ineffectiveness like similar civil service organisations. Empirical studies are 
required to explain this apparent relapse into unethical conducts by procurement professionals, entities and officers.

\section{Previous studies}

Most previous studies identified unethical practices in the construction industry, without being solely specific to the tendering stage of procurement (Adnan et al. 2012; Ameyaw et al. 2017; Le et al. 2014; Shan et al. 2016; Vee \& Skitmore 2003). Ray et al. (1999), who focused solely on the tendering stage of procurement, concentrated on ascertaining the extent to which the principles enshrined in the Interim Australian Standard Code of Tendering were accepted and applied in the Australian construction industry. The present study will differ by being focused on the principles enshrined in the PPA 2007 and other procurement laws within Nigeria. Australia as a developed economy differs in terms of procurement environment from Nigeria, which is a developing economy.

Generally, the identified unethical practices in the construction industry include bribery, collusion, cover pricing and falsification of qualification documents, among others (Abdul-Rahman et al. 2010; Azher, Selph \& Maqsood 2011; Bowen et al. 2007a; Shakantu 2006; Vee \& Skitmore 2003). Table 1 shows a fuller list of the unethical practices identified in past literature. Good as these studies are, they fail to comprehensively reflect the unethical conduct proscribed by the procurement laws in Nigeria. In public sector procurement in Nigeria, except for state-funded projects in states that have no procurement laws, to be ethical essentially means to comply with the procurement laws. The existing literature also offers little insight on the group that exhibits more unethical tendering practices - the clients and consultants or the contractors, the federal or state government projects.

\section{Tendering ethics of clients and consultants in Nigerian public procurement}

Government procurement activities are carried out by inhouse staff of public procuring entities and the consultants engaged with respect to the projects. These two groups of officers synergistically oversee the procurement process. However, their practices in this regard are circumscribed by the procurement laws.

The public sector in Nigeria is in three tiers: the federal, state and local governments. The federal and state governments determine their own procurement procedures, while the local governments follow their respective states' procurement laws. The framework of public procurement in Nigeria is shown in Figure 3. Twenty-four states in Nigeria have enacted their own procurement laws, including Lagos, Rivers, Edo, Delta and Taraba (Agbor 2012; Usman 2014). The PPA 2007 only applies to all the states of the federation where up to $35 \%$ of the project funds will be sourced from the federation's share of the Consolidated Revenue Fund (FRN 2007a). The above marks a departure of Nigeria's procurement laws from those of countries like Ghana that have a single procurement law (the Public Procurement Law 2003 [Act 663]) that applies nationwide.
TABLE 1: Unethical tendering practices from previous studies.

\begin{tabular}{|c|c|}
\hline Reference & Tendering practices \\
\hline \multirow{6}{*}{$\begin{array}{l}\text { Abdul-Rahman } \\
\text { et al. (2010) }\end{array}$} & Under-bidding, bid shopping, bid cutting \\
\hline & Bribery, corruption, negligence \\
\hline & Front-loading, claims game, payment game \\
\hline & Unfair and dishonest conduct, fraud, collusion \\
\hline & Conflict of interest, change order game \\
\hline & Cover pricing, withdrawal of tender \\
\hline \multirow{8}{*}{$\begin{array}{l}\text { Vee and Skitmore } \\
\text { (2003) }\end{array}$} & Compensation of tendering cost \\
\hline & $\begin{array}{l}\text { Client divulging more tender information to preferred } \\
\text { tenderers and withholding vital information from the other } \\
\text { tenderers }\end{array}$ \\
\hline & Bias in tendering evaluations to favour major contractors \\
\hline & Re-tendering after publishing prices \\
\hline & $\begin{array}{l}\text { Re-tendering using a consultant's design, which they } \\
\text { obtained during the first tender }\end{array}$ \\
\hline & Shopping prices after tenders closed \\
\hline & $\begin{array}{l}\text { Clients preselecting consultant then calling tenders to fulfil } \\
\text { organisational or statutory requirements }\end{array}$ \\
\hline & $\begin{array}{l}\text { Competitors overstating their capacity and qualifications to } \\
\text { secure work; competitors overstating their experience and } \\
\text { capabilities and falsification of qualifications }\end{array}$ \\
\hline \multirow[t]{2}{*}{ Azher et al. (2011) } & Bid shopping, fraud, collusion, overbilling \\
\hline & Procurement of substandard or defective materials \\
\hline \multirow[t]{3}{*}{ Adnan et al. (2012) } & Bribery, fraud, dishonesty and unfairness \\
\hline & Over-statement of capacity and qualification to secure work \\
\hline & Cover pricing, bid cutting, unfair treatment of contractors \\
\hline Bowen et al. (2007a) & $\begin{array}{l}\text { Collusion, fraud, bribery, negligence, dishonesty and unfair } \\
\text { practices }\end{array}$ \\
\hline Shakantu (2006) & $\begin{array}{l}\text { Bid rigging, lowballing, bribery } \\
\text { Fake declaration of capability, invalid requests for proposals }\end{array}$ \\
\hline \multirow[t]{4}{*}{ Wells (2013) } & Bribery to get onto tender lists or to win contracts \\
\hline & $\begin{array}{l}\text { Submitting several bids from the same contractor under } \\
\text { different names }\end{array}$ \\
\hline & $\begin{array}{l}\text { Front-loading the tender, forming a cartel } \\
\text { Submitting false information in documents }\end{array}$ \\
\hline & $\begin{array}{l}\text { Putting in a low bid and then making claims or skimping on } \\
\text { materials }\end{array}$ \\
\hline Shan et al. (2016) & $\begin{array}{l}\text { Misusing prequalification requirements, leaking vital } \\
\text { information by the client, inflating tender price, fake } \\
\text { tendering, intervening in tender evaluation, splitting a large } \\
\text { project illegally, lack of publicity, insufficient tender time, } \\
\text { absence of tender, bias in tender evaluation, } \\
\text { misrepresentation of qualification certificates, collective } \\
\text { collusive tendering by helping one another, helping the } \\
\text { pre-established tenderer by giving up the contract, leaking } \\
\text { vital information by the bidding consultant }\end{array}$ \\
\hline
\end{tabular}

It is unclear whether the PPA 2007 has led to more ethical tendering processes in Federal Government of Nigeria's and compliant states' tendering processes. The peculiarity of the PPA 2007 and the states' public procurement laws seem to be that they prescribe how the ethical requirements listed by England (2011) can be met and specify punishments for deviations from the ethical principles. The tendering practices of clients and consultants in the states without procurement laws are largely left to their personal ethics and the codes of conduct of their respective professions. However, as Figure 3 shows, in some projects, federal government agencies influence or 'mentor' their state counterparts in the administration of projects for which both levels of government are responsible. According to Ameh and Odusami (2010b), relativism is the Nigerian construction industry professionals' dominant ethical ideology. Impliedly, in order for their good behaviour to remain stable and consistent, they must also be put in the proper kind of work situations, perhaps using laws. England (2011:3) reasoned that while personal ethics are a reflection of beliefs, values, personality and background, any propensity 


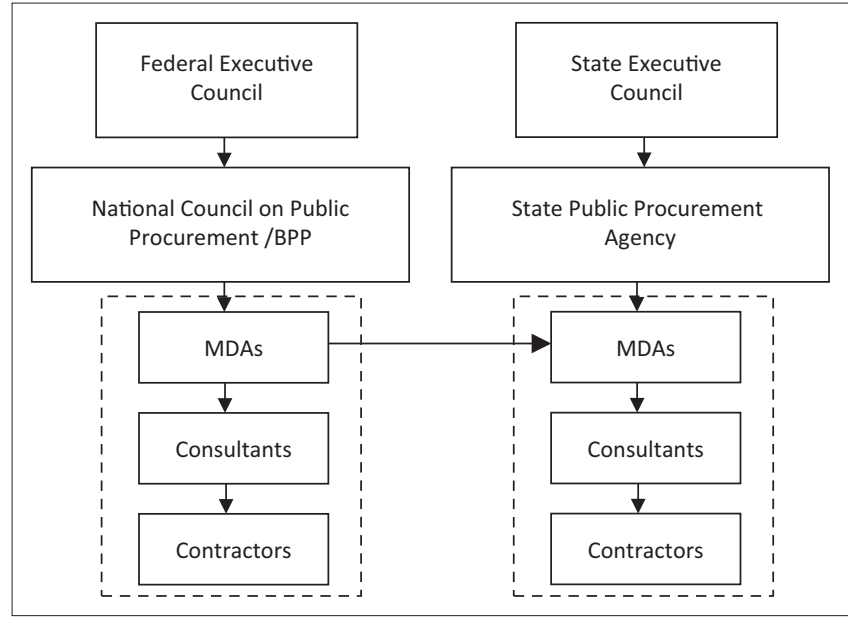

FIGURE 3: Nigerian public procurement framework.

a person may have towards ethical conduct is influenced by the value systems of their employing organisation. In some countries like Nigeria and Ghana, these value systems have been framed into procurement laws to govern the ethical dilemmas in tendering processes for public procurement. Yet corruption, anti-competitive behaviours and other unethical practices are considered to be rampant in both countries. These latter unethical practices have scarcely been studied in the light of the procurement laws. Mason (2009) highlighted that procurement officers may continue to engage in unethical practices even though they know the risks involved.

In this work, clients are the state and federal government procuring entities. The Public Procurement Regulations for Goods and Works (PPRGW) (2007), applicable to all Federal Government of Nigeria projects (there are similar regulations in the states that have enacted procurement laws), prescribes rules to guide procuring entities during tendering in order not to breach the PPA 2007 (FRN 2007b). It would be unethical and illegal for procurement officers of government to infringe upon these rules.

Section 49 of the PPRGW (2007) states that 'Procuring Entities shall give a time gap of at least 6 weeks between the date of an advert inviting bids and the deadline for submission of bids' (FRN 2007b). An advert of a shorter duration would be unethical and illegal. Likewise, the PPRGW (2007) makes it mandatory for tender adverts to be made in at least two national dailies and the Federal Tenders Journal (Section 50). These measures should ensure that anti-competitive behaviours are forestalled in public procurement in Nigeria. However, discontent with the ethical standards exhibited by clients and their consultants in public procurements in the country persists. For example, $72 \%$ of the construction professionals that responded to Ameh and Odusami's (2010a) study confessed to having been involved in unethical conduct. Likewise, Ameh and Odusami (2010b) indicated the existence of endemic corruption and unethical practices in the Nigerian construction industry.

\section{Tendering ethics of contractors}

Globally, unethical practices by contractors are known to include under-bidding, bid shopping, bid cutting, bribery and gratuities, front-end loading, claims game, unfair or dishonest conduct, cover pricing or withdrawal of tender, among others (Gentry 1990; Rahman et al. 2007). It is possible that because of variations in the applicable codes of conduct and procurement laws, the manifestation of unethical practices will differ for different climes. In Nigeria's case, Alutu (2007) observed that contractors obtain vital project information by paying some money to the procuring entities and that the probability of winning a contract in Nigeria equally depended on the payment of kickbacks to officials of the procuring entity. It is not clear whether these unethical practices persist today. The PPA 2007 proscribes both the giving and the receiving of gratifications, howsoever named, during construction procurement. Particularly, the introduction of the Bank Verification Number (BVN) in the Nigerian banking system makes it easy for prosecutors to trace monies paid as kickbacks by bribe givers to the bribe receivers (Omodunbi et al. 2016). Thus, unethical individuals in the Nigerian construction industry may have invented different strategies for the transmission of bribes and gratuities during tendering that require investigation.

\section{Research methodology Research design}

Mixed method design was adopted in this study. Mixed method strategy involves the collection of both qualitative and quantitative data in research (Greene, Caracelli \& Graham 1989). In this case, tendering unethical practices were identified qualitatively from the PPA 2007, the procurement laws of the states and the PPRGW 2007. The respondents were asked to indicate quantitative opinions based on a Likert scale of 1 to 5 in response to questions on the prevalence of unethical tendering practices in Nigeria. It was beneficial to combine the qualitative and quantitative approaches in this study. While the qualitative data aided the identification of the unethical practices, the quantitative data made it possible to carry out statistical analysis on them.

\section{Study area}

The study was carried out in the states of Edo and Akwa Ibom, Nigeria. Whereas Edo State has enacted its public procurement law, Akwa Ibom State has not passed a similar law. The choice of these states was aimed at making the findings more generalisable. Moreover, the two states have a robust number of construction contracting and consultancy firms from which the required data for the study could be obtained. This is because the states are in the Niger Delta region of Nigeria, which has a relatively higher income per capita and consequently a more vibrant construction industry than most other states of Nigeria.

\section{Study questionnaires}

The unethical practices of clients or consultants and contractors were obtained from previous studies and from 
the provisions of the various laws, codes, regulations and guidelines governing tendering in Nigeria's federal and state governments. Two data questionnaires were made for the study. Similar previous studies equally used questionnaires as the instrument for primary data collection (Shan et al. 2016; Vee \& Skitmore 2003). Although the contents of the questionnaires were substantially similar, one was specifically addressed to clients or consultants, while the other was addressed to the contractors. The questionnaires were divided into four sections. Section A focused on the demographic data of the respondents; section B focused on the unethical tendering practices of contractors; and sections $\mathrm{C}$ and D dwelt on the unethical tendering practices of the clients or consultants at the tender invitation and the tender evaluation and award stages, respectively. The questionnaires were given to four senior academics to vet and suggestions leading to improvements in the coinage of the variables were made on the final questionnaires. A Cronbach's alpha test of the questionnaire items yielded $\alpha=0.998, N=53$, indicating an acceptable level of scale reliability based on previous studies (Gliem \& Gliem 2003; Kline 1999). The questionnaire was distributed between April and November 2017 and required approximately $30 \mathrm{~min}$ to fill.

\section{Study population}

The consultants and contractors covered by the study were obtained from the list of registered contractors in the government agencies of interest to the study (see Table 2). This was carried out in a pilot study in which the government agencies were requested to help the researchers by offering their lists of registered contractors and consultants. However, other consultants - architects, quantity surveyors and engineers - who had participated in public procurement but were not on the lists obtained from the ministries, departments and agencies (MDAs) were included in order to increase the coverage of the survey. It was considered that the bias introduced into the study by this approach would be substantially outweighed by the benefits of increasing the coverage of the study. Because studies of this nature are susceptible to social desirability bias, especially when one is dealing with the public sector (King \& Bruner 2000; Zhang et al. 2017), Gordon's (1987) suggestions on reducing the bias were adopted in the study questionnaires. Thus, the confidentiality and importance of the information to be provided were stressed to the respondents. The respondents were not required to include the names of their organisations in the questionnaire (Dodd-McCue \& Tartaglia 2010). The contractors rated their frequency of practice of the identified unethical tendering practices and also rated a set of identified unethical tendering practices by their public sector clients and their consultants. The consultants and clients were likewise asked to rate those of the contractors. To test for possible biases, each group's rating of itself was compared to the ratings on the same traits by the other group.

The contractors and consultants were asked to indicate their predominant sources of workload. On the basis of this, they were regarded as either state public sector-focused or federal public sector-focused. The details of the questionnaire administration are shown in Table 2.

In order to minimise non-response bias (Armstrong \& Overton 1977), the phone and/or emails of respondents were collected, and they were gently reminded of the survey until they responded. Additionally, the questionnaires were kept simple, with close-ended questions that mainly required the respondents to tick the appropriate level of responses. The questionnaires were purposively targeted at middle and top management staff in the organisations of interest to the study. Primarily, the questionnaires focused on organisations and construction consultants for MDAs under the federal and state Ministries of Education, Health and Power, Works and Housing. The federal Ministries of Education, Health and Power, Works and Housing have a presence in most states of the federation.

A five-point Likert scale (1, not prevalent; 2, moderately prevalent; 3, prevalent; 4, very prevalent; 5, extremely prevalent) was used for the study.

TABLE 2: Questionnaire distribution and return.

\begin{tabular}{|c|c|c|c|c|c|}
\hline Type of organisation & State & $\begin{array}{c}\text { Number of questionnaires } \\
\text { distributed }\end{array}$ & $\begin{array}{l}\text { Number of questionnaires } \\
\text { returned }\end{array}$ & $\begin{array}{l}\text { Number of questionnaires } \\
\text { used in the analysis }\end{array}$ & $\begin{array}{l}\text { Per cent of distributed } \\
\text { questionnaires used in analysis }\end{array}$ \\
\hline \multirow[t]{2}{*}{ Federal procuring entities } & AKS & 12 & 11 & 11 & 92 \\
\hline & Edo & 13 & 9 & 9 & 69 \\
\hline \multirow[t]{2}{*}{ Federal consultant } & AKS & 8 & 5 & 5 & 63 \\
\hline & Edo & 14 & 8 & 7 & 50 \\
\hline \multirow[t]{2}{*}{ Federal contractor } & AKS & 8 & 6 & 6 & 75 \\
\hline & Edo & 10 & 9 & 9 & 90 \\
\hline Subtotal & - & 65 & 48 & 47 & - \\
\hline \multirow[t]{2}{*}{ State procuring entities } & AKS & 11 & 10 & 8 & 73 \\
\hline & Edo & 15 & 15 & 14 & 93 \\
\hline \multirow[t]{2}{*}{ State consultant } & AKS & 15 & 11 & 10 & 67 \\
\hline & Edo & 17 & 8 & 8 & 47 \\
\hline \multirow[t]{2}{*}{ State contractor } & AKS & 22 & 16 & 16 & 73 \\
\hline & Edo & 18 & 17 & 17 & 94 \\
\hline Subtotal & - & 98 & 77 & 73 & - \\
\hline Total & - & 163 & 125 & 120 & - \\
\hline
\end{tabular}

AKS, Akwa Ibom State; Edo, Edo State. 


\section{Methods of data analysis}

The variables of the study were ranked using prevalence indices the formula for which is shown in Eqn 1.

$$
P_{i}=\sum \frac{a f}{A N}
$$

where $P_{\mathrm{i}}=$ prevalence index, $a=$ a weight assigned the $i$ th variable ranging from 1 to $5, f=$ frequency of $a, A=$ the highest rank (5) and $N=$ number of variables. The formula was also used to compute $\mathrm{P}_{\mathrm{ia}}, \mathrm{P}_{\text {if }}$ and $\mathrm{P}_{\mathrm{is}}$, which are the respective performance indices of the variables when all variables in a group were combined and when the federal and state government responses were separately considered, respectively.

When all the unethical tendering practices were combined, the variables were designated as 'not prevalent' where the mean is $\leq 2.49$, 'prevalent' where the mean is $\geq 2.5 \leq 3.59$ and 'highly prevalent' where the mean is $\geq 3.6$. Differences in the opinions of the respondents were determined using the Mann-Whitney $U$ test because the data were on the ordinal scale.

\section{Hypothesis of the study}

Ho: $_{1}$ : The responses on contractors' unethical tendering practices are similar across the federal and state levels.

Ho: The responses on clients' or consultants' unethical tendering practices at the tender invitation stage are similar across the federal and state levels.

$\mathbf{H o}_{3}$ : The responses on the clients' or consultants' unethical tendering practices at the tender evaluation and award stages are similar across the federal and state levels.

Ho $_{4}$ : The responses on clients' or consultants' unethical tendering practices are similar at the invitation to tender and the tender evaluation and award stages

\section{Results}

Based on warnings from previous studies, the hypothesis that no significant difference exists between the rankings of the sets of unethical tendering practices by the consultants or clients and contractor groups was tested using the Mann-Whitney $\mathrm{U}$ test. With $p=0.038$, which is $<0.05$, the null hypothesis was rejected. It was concluded that a significant difference exists between the opinions of the two groups. This exposed a tendency by the clients or consultants and the contractor groups to trade blame with each other over unethical tendering practices. It also pointed to the existence of social desirability bias within the data gathered for the study.

Given this outcome, the responses were sorted in the order of federal and state public sector responses. In each case, the contractors' and clients' or consultants' responses were combined and averaged to obtain the average mean reported in the results.

The results of the analyses were separately presented for contractors' unethical tendering practices (Table 3), clients' or consultants' unethical tendering practices at the invitation to tender stage (Table 4), clients' or consultants' unethical tendering practices at the tender evaluation and award stage (Table 5) and then pooled together and presented in Table 6.

\section{Unethical tendering practices of contractors}

The results of the respondents' ranking of contractors' unethical tendering practices are shown in Table 3. From the table, the state respondents ranked competitors offer bribes to gain access to confidential tendering information (C1) $\left(P_{\text {is }}=4.33\right)$ first among the variables in this group. The federal respondents, however, ranked it second $\left(P_{\text {if }}=4.26\right)$. When the responses were pooled together and analysed, the variable came first $\left(P_{\mathrm{ia}}=4.30\right)$ as the most prevalent unethical tendering

TABLE 3: Responses on unethical tendering practices of contractors.

\begin{tabular}{|c|c|c|c|c|c|c|c|c|c|c|}
\hline \multirow[t]{2}{*}{$\mathrm{S} / \mathrm{N}$} & \multirow[t]{2}{*}{ Unethical tendering practices of contractors } & \multicolumn{3}{|c|}{ All } & \multicolumn{3}{|c|}{ Federal responses } & \multicolumn{3}{|c|}{ State responses } \\
\hline & & $\boldsymbol{P}_{\mathrm{ia}}$ & $N$ & $\boldsymbol{R}$ & $\boldsymbol{P}_{\text {if }}$ & $N$ & $\boldsymbol{R}$ & $\boldsymbol{P}_{\text {is }}$ & $N$ & $R$ \\
\hline $\mathrm{C} 1$ & Competitors offer bribes to gain access to confidential tendering information. & 4.30 & 120 & 1 & 4.26 & 47 & 2 & 4.33 & 73 & 1 \\
\hline $\mathrm{C} 2$ & Competitors overstate their capacity, experience and qualifications to secure construction contracts. & 4.07 & 120 & 2 & 4.45 & 47 & 1 & 3.82 & 73 & 4 \\
\hline C3 & The same owner(s) use different firms to tender for the same project. & 3.95 & 120 & 3 & 4.15 & 47 & 3 & 3.82 & 73 & 5 \\
\hline C4 & Competitors use influential persons in society to attempt to influence the outcome of the tendering process. & 3.91 & 120 & 4 & 3.87 & 47 & 4 & 3.93 & 73 & 2 \\
\hline C5 & $\begin{array}{l}\text { Tenderers offer gratuities (non-requested bribes or favours) in order to earn favourable consideration during } \\
\text { tendering. }\end{array}$ & 3.78 & 120 & 5 & 3.7 & 47 & 5 & 3.84 & 73 & 3 \\
\hline C6 & $\begin{array}{l}\text { A qualified contractor facilitates participation of an unqualified contractor in tendering by providing its } \\
\text { qualification certificates. }\end{array}$ & 3.23 & 120 & 6 & 3.57 & 47 & 6 & 3.01 & 73 & 6 \\
\hline $\mathrm{C7}$ & $\begin{array}{l}\text { Tenderers threaten persons in the procuring entity or consultants when they fail to win or are likely to lose } \\
\text { during tendering. }\end{array}$ & 3.06 & 120 & 7 & 3.19 & 47 & 7 & 2.97 & 73 & 7 \\
\hline C8 & Tenderers alter procurement documents with intent to influence the outcome of a tender proceeding. & 2.90 & 120 & 8 & 2.94 & 47 & 9 & 2.92 & 73 & 8 \\
\hline C9 & $\begin{array}{l}\text { Agree on the contractor to submit winning tender while your firm puts forward a bid that is higher than the } \\
\text { tender of the designated bidder. }\end{array}$ & 2.74 & 120 & 9 & 2.72 & 47 & 11 & 2.75 & 73 & 9 \\
\hline $\mathrm{C} 10$ & Be part of a group of competitors that take turns to win contracts from a particular public client. & 2.47 & 120 & 10 & 2.43 & 47 & 13 & 2.49 & 73 & 10 \\
\hline C12 & Carve out markets in different segments and agree not to compete in each other's segment. & 2.39 & 120 & 12 & 2.79 & 47 & 10 & 2.14 & 73 & 12 \\
\hline $\mathrm{C} 13$ & Submission of tenders known to be too high to be accepted. & 2.31 & 120 & 13 & 2.43 & 47 & 12 & 2.23 & 73 & 11 \\
\hline C14 & Submission of tenders that contain special conditions that are known to be undesirable to the client. & 2.23 & 120 & 14 & 2.38 & 47 & 14 & 2.12 & 73 & 13 \\
\hline C15 & Agree to refrain from tendering so that one of the competitors can win the contract. & 2.14 & 120 & 15 & 2.23 & 47 & 15 & 2.08 & 73 & 15 \\
\hline
\end{tabular}

$P_{\mathrm{if}} P_{\text {is }}$ and $P_{\mathrm{ia}}$, respective prevalence indices for federal, state and combined federal and state practices; R, rank; $\mathrm{N}$, number of responses; $\mathrm{S} / \mathrm{N}$, Serial number; $\mathrm{C}$, Contractors' unethical tendering practices. 
TABLE 4: Responses on the unethical tendering practices of clients or consultants at the invitation to tender stage. $\mathrm{S} / \mathrm{N}$ Tendering practices by clients or consultants: Invitation to tender stage

\begin{tabular}{|c|c|c|c|c|c|c|c|c|c|c|}
\hline & & & & & & & & & \\
\hline & & $P_{\text {ia }}$ & $N$ & $\boldsymbol{R}$ & $P_{\text {if }}$ & $N$ & $\boldsymbol{R}$ & $\boldsymbol{P}_{\text {is }}$ & $N$ & $R$ \\
\hline $\mathrm{T} 1$ & Bid opening, tender evaluation or award are unjustifiably delayed after receipt of tenders. & 3.91 & 120 & 1 & 3.94 & 47 & 1 & 3.89 & 73 & 1 \\
\hline $\mathrm{T} 2$ & No room for contractors to seek clarification concerning the bid documents. & 3.77 & 120 & 2 & 3.6 & 47 & 6 & 3.88 & 73 & 2 \\
\hline T3 & $\begin{array}{l}\text { Firms known to have used corrupt, fraudulent, collusive or coercive practices are not sanctioned in any way } \\
\text { during tendering. }\end{array}$ & 3.73 & 120 & 3 & 3.62 & 47 & 5 & 3.81 & 73 & 3 \\
\hline T4 & Client representative hinting tenderer to inflate tender price in return for kickback. & 3.68 & 120 & 4 & 3.87 & 47 & 2 & 3.56 & 73 & 5 \\
\hline T5 & Client divulging more information to preferred bidder. & 3.68 & 120 & 5 & 3.6 & 47 & 7 & 3.74 & 73 & 4 \\
\hline T6 & Procuring entity's staff help some contractors to fill out tender documents during bidding. & 3.59 & 120 & 6 & 3.66 & 47 & 4 & 3.55 & 73 & 6 \\
\hline T8 & Leakage of tender price in return for payment. & 3.35 & 120 & 8 & 3.32 & 47 & 11 & 3.37 & 73 & 7 \\
\hline T9 & Project requirements overstated or tailored to fit a preferred bidder. & 3.28 & 120 & 9 & 3.4 & 47 & 9 & 3.21 & 73 & 12 \\
\hline T10 & Client set excessively short time for preparation and submission of tenders. & 3.25 & 120 & 10 & 3.3 & 47 & 12 & 3.22 & 73 & 11 \\
\hline T11 & Members of the procurement committee of procuring entities are always communicating with bidders. & 3.22 & 120 & 11 & 3.32 & 47 & 10 & 3.15 & 73 & 13 \\
\hline T12 & The tender evaluation process not being confidential. & 3.13 & 120 & 12 & 2.83 & 47 & 15 & 3.32 & 73 & 8 \\
\hline T13 & Tendering is conducted by government MDAs with insufficient or no budgetary allocation. & 3.08 & 120 & 13 & 3.74 & 47 & 3 & 2.64 & 73 & 20 \\
\hline T14 & Criteria for selecting winner not made public. & 3.06 & 120 & 14 & 2.68 & 47 & 17 & 3.3 & 73 & 9 \\
\hline T16 & $\begin{array}{l}\text { Contractors are forced to engage certain domestic subcontractors in order to stand a chance of winning a } \\
\text { tender. }\end{array}$ & 2.90 & 120 & 16 & 2.57 & 47 & 19 & 3.11 & 73 & 14 \\
\hline T17 & Firms in which persons in the procuring entity have interests participate in tendering and are not disqualified. & 2.90 & 120 & 17 & 2.83 & 47 & 16 & 2.95 & 73 & 16 \\
\hline T18 & Withholding vital information from other bidders. & 2.83 & 120 & 18 & 3 & 47 & 14 & 2.73 & 73 & 17 \\
\hline T19 & $\begin{array}{l}\text { Intentional choice of inappropriate tendering approach (e.g. use of negotiation where open tendering should } \\
\text { have been conducted). }\end{array}$ & 2.68 & 120 & 19 & 2.68 & 47 & 17 & 2.7 & 73 & 19 \\
\hline T20 & Lack of public notice for tender invitation. & 2.53 & 120 & 20 & 2.26 & 47 & 23 & 2.7 & 73 & 18 \\
\hline $\mathrm{T} 21$ & Bids are submitted prior to advertisement of contract. & 2.45 & 120 & 21 & 2.3 & 47 & 22 & 2.55 & 73 & 21 \\
\hline T22 & Some firms are allowed to bid using unverifiable means like phone calls. & 2.37 & 120 & 22 & 2.32 & 47 & 21 & 2.4 & 73 & 22 \\
\hline T23 & $\begin{array}{l}\text { Bids are opened, tampered with or their contents divulged prior to the appointed time for the public opening } \\
\text { of bids or other documents. }\end{array}$ & 2.30 & 120 & 23 & 2.47 & 47 & 20 & 2.19 & 73 & 23 \\
\hline T24 & Bids are submitted on non-working days. & 2.02 & 120 & 24 & 2.15 & 47 & 24 & 1.93 & 73 & 24 \\
\hline
\end{tabular}

$P_{i,} P_{i}$ and $P_{i,}$, respective prevalence indices for federal, state and combined federal and state practices; $\mathrm{R}$, rank; $\mathrm{N}$, number of responses; MDAs, ministries, departments and agencies; $\mathrm{S} / \mathrm{N}$, Serial number; $T$, Tendering practices by clients or consultants at invitation to tender stage.

TABLE 5: Responses on the unethical tendering practices of clients or consultants at the tender evaluation and award stage.

\begin{tabular}{|c|c|c|c|c|c|c|c|c|c|c|}
\hline \multirow[t]{2}{*}{$\mathrm{S} / \mathrm{N}$} & \multirow[t]{2}{*}{ Tendering practices by clients or consultants: Tender evaluation and award stage } & \multicolumn{3}{|c|}{ All } & \multicolumn{3}{|c|}{ Federal responses } & \multicolumn{3}{|c|}{ State responses } \\
\hline & & $\boldsymbol{P}_{\mathrm{ia}}$ & $N$ & $\boldsymbol{R}$ & $\boldsymbol{P}_{\text {if }}$ & $N$ & $\boldsymbol{R}$ & $\boldsymbol{P}_{\text {is }}$ & $N$ & $\boldsymbol{R}$ \\
\hline E1 & $\begin{array}{l}\text { Chief executive of client organisation intervenes in tender evaluation and helps his or her preferred tenderer } \\
\text { win the contract. }\end{array}$ & 3.93 & 120 & 1 & 3.72 & 47 & 3 & 4.05 & 73 & 1 \\
\hline E2 & Bias in tender evaluation to favour preferred tenderer. & 3.87 & 120 & 2 & 3.77 & 47 & 2 & 3.93 & 73 & 2 \\
\hline E3 & Those who lost during tendering are not informed about the reasons why they lost, even upon request. & 3.87 & 120 & 3 & 3.85 & 47 & 1 & 3.88 & 73 & 3 \\
\hline E4 & Destruction or loss of records of tendering processes soon after award. & 3.73 & 120 & 4 & 3.53 & 47 & 6 & 3.85 & 73 & 4 \\
\hline E5 & Client preselecting the contractor and then calling for tenders to fulfil statutory requirements (fake tendering). & 3.45 & 120 & 5 & 3.68 & 47 & 4 & 3.3 & 73 & 6 \\
\hline E6 & Unclear definition of selection criteria, in which case winner selected based on subjective measures. & 3.38 & 120 & 6 & 3.09 & 47 & 9 & 3.58 & 73 & 5 \\
\hline E7 & Evaluation of tenders not done correctly as per the earlier announced rules. & 3.31 & 120 & 7 & 3.68 & 47 & 5 & 3.07 & 73 & 8 \\
\hline E8 & $\begin{array}{l}\text { Accounting officers of procuring entities do not entertain complaints from tenderers relating to the tendering } \\
\text { process. }\end{array}$ & 3.26 & 120 & 8 & 3.19 & 47 & 8 & 3.3 & 73 & 7 \\
\hline E9 & $\begin{array}{l}\text { Inexplicable or unjustifiable cancelation of a tendering process, especially because a preferred bidder is likely } \\
\text { to or has lost. }\end{array}$ & 2.88 & 120 & 9 & 3.19 & 47 & 7 & 2.68 & 73 & 11 \\
\hline E10 & Phantom contractors submit bids and are awarded contracts. & 2.76 & 120 & 10 & 2.77 & 47 & 11 & 2.75 & 73 & 10 \\
\hline E11 & Tender opening ceremonies are not conducted. & 2.70 & 120 & 11 & 2.98 & 47 & 10 & 2.52 & 73 & 13 \\
\hline E13 & $\begin{array}{l}\text { Chief executive of client organisation awards contract to preferred contractor without necessary tendering } \\
\text { procedure. }\end{array}$ & 2.53 & 120 & 13 & 2.34 & 47 & 14 & 2.64 & 73 & 12 \\
\hline E14 & Bids not read out during tender opening are considered during tender evaluation. & 2.48 & 120 & 14 & 2.55 & 47 & 12 & 2.42 & 73 & 14 \\
\hline
\end{tabular}

$P_{\mathrm{if}} P_{\text {is }}$ and $P_{\mathrm{ia}}$, respective prevalence indices for federal, state and combined federal and state practices; $\mathrm{R}$, rank; $\mathrm{N}$, number of responses; $\mathrm{S} / \mathrm{N}$, Serial number; $\mathrm{E}$, Tendering practices by clients or consultants at tender evaluation and award stage.

practice of contractors. $\mathrm{C} 1$ equally ranked highest $\left(P_{\mathrm{i}}=4.30\right)$ when all the unethical tendering practices were combined and ranked (Table 6). In Table 3, C1 was followed by competitors overstating their capacity, experience and qualifications to secure construction contracts $(\mathrm{C} 2),\left(P_{\mathrm{ia}}=4.07\right)$, which was ranked first by the federal government respondents $\left(P_{\text {if }}=4.45\right)$ and fourth by the state government respondents $\left(P_{\text {is }}=3.82\right)$. Overall, $\mathrm{C} 2$ ranked second $\left(P_{\mathrm{i}}=4.04\right)$ (Table 6$)$. This suggests that the increasingly stringent procurement regulations in the country have increased the premium placed on confidential tendering information by contractors. The findings further indicate that, in order to meet the requirements of the procurement laws and regulations, the contractors use falsified company information.

Among this group of variables, agree to refrain from tendering so that one of the competitors can win the contract $(\mathrm{C} 15)\left(P_{\mathrm{ia}}=2.14\right.$, $\left.P_{\text {if }}=2.23, P_{\text {is }}=2.08\right)$ was ranked the lowest and was found not to be prevalent in the study area $\left(P_{\mathrm{i}}=2.14\right)$ (see Table 6). 
TABLE 6: Overall ranking of unethical tendering practices in the research area.

\begin{tabular}{ll}
\hline Code Unethical tendering practice \\
\hline C1 & Competitors offer bribes to gain access to confidential tendering information. \\
C2 & Competitors overstate their capacity, experience and qualifications to secure construction contracts. \\
C3 & The same owner(s) use different firms to tender for the same project. \\
E1 Chief executive of client organisation intervenes in tender evaluation and helps his or her preferred tenderer win the \\
contract.
\end{tabular}

E4 Destruction or loss of records of tendering processes soon after award.

E2 Bias in tender evaluation to favour preferred tenderer.

T5 Client divulging more information to preferred bidder.

T4 Client representative hinting to tenderer to inflate tender price in return for kickback.

T6 Procuring entity's staff help contractor fill out tender documents during bidding.

E5 Client preselecting the contractor and then calling for tenders to fulfil statutory requirements (fake tendering).

E6 Unclear definition of selection criteria, in which case winner selected based on subjective measures.

T7 Splitting of large projects into several small projects to evade due process requirements.

T8 Leakage of tender price in return for payment.

E7 Evaluation of tenders not done correctly as per the earlier announced rules.

T9 Project requirements overstated or tailored to fit a preferred bidder.

E8 Accounting officers of procuring entities do not entertain complaints from tenderers relating to the tendering process.

T10 Client sets excessively short time for preparation and submission of tenders.

C6 A qualified contractor facilitates participation of an unqualified contractor in tendering by providing its qualification certificates.

T11 Members of the procurement committee of procuring entities are always communicating with bidders.

T12 The tender evaluation process not being confidential.

T13 Tendering is conducted by government MDAs with insufficient or no budgetary allocation.

T14 Criteria for selecting winner not made public.

C7 Tenderers threaten persons in the procuring entity or consultants when they fail to win or are likely to lose during tendering.

T15 Some firms that were prequalified to bid are not invited to bid.

C8 Tenderers alter procurement documents with intent to influence the outcome of a tender proceeding.

T17 Firms in which persons in the procuring entity have interests participate in tendering and are not disqualified.

T16 Contractors are forced to engage certain domestic subcontractors in order to stand a chance of winning a tender.

E9 Inexplicable or unjustifiable cancelation of a tendering process, especially because a preferred bidder is likely to or has lost.

T18 Withholding vital information from other bidders.

E10 Phantom contractors submit bids and are awarded contracts.

C9 Agree on the contractor to submit winning tender while your firm puts forward a bid that is higher than the tender of the designated bidder.

E11 Tender opening ceremonies are not conducted.

T19 Intentional choice of inappropriate tendering approach (e.g. use of negotiation where open tendering should have been conducted).

E12 Shopping for price after close of tenders.

T20 Lack of public notice for tender invitation.

E13 Chief executive of client organisation awards contract to preferred contractor without necessary tendering procedure.

E14 Bids not read out during tender opening are considered during tender evaluation.

C10 Be part of group of competitors that take turns to win contracts from a particular public client.

T21 Bids are submitted prior to advertisement of contract. A collusive agreement is reached that the tenderer provid
tenderer to win the contract by giving up the contract.

C12 Carve out markets in different segments and agree not to compete in each other's segment.

T22 Some firms are allowed to bid using unverifiable means like phone calls.

C13 Submission of tenders known to be too high to be accepted.

T23 Bids are opened, tampered with or their contents divulged prior to the appointed time for the public opening of bids or other documents.

C14 Submission of tenders that contain special conditions that are known to be undesirable to the client.

C15 Agree to refrain from tendering so that one of the competitors can win the contract.

T24 Bids are submitted on non-working days.

$\begin{array}{ccccl}\boldsymbol{N} & \boldsymbol{P}_{\mathrm{i}} & \text { SD } & \text { Rank } & \text { Prevalence } \\ 120 & 4.30 & 0.89 & 1 & \text { HP } \\ 120 & 4.04 & 1.27 & 2 & \text { HP } \\ 120 & 3.95 & 1.17 & 3 & \text { HP } \\ 120 & 3.93 & 1.01 & 4 & \text { HP } \\ 120 & 3.91 & 1.12 & 5 & \text { HP } \\ 120 & 3.91 & 1.16 & 6 & \text { HP } \\ 120 & 3.87 & 1.04 & 7 & \text { HP } \\ 120 & 3.78 & 0.96 & 8 & \text { HP }\end{array}$

$\begin{array}{lllll}120 & 3.77 & 1.14 & 9 & \mathrm{HP}\end{array}$

$\begin{array}{lllll}120 & 3.73 & 1.06 & 10\end{array}$

$\begin{array}{lllll}120 & 3.73 & 1.04 & 11 & \text { HP }\end{array}$

$\begin{array}{lllll}120 & 3.72 & 0.96 & 12 & \text { HP }\end{array}$

$\begin{array}{lllll}120 & 3.68 & 0.95 & 13 & \text { HP }\end{array}$

$\begin{array}{lllll}120 & 3.68 & 1.07 & 14 & \text { HP }\end{array}$

$\begin{array}{lllll}120 & 3.59 & 1.12 & 15 & P\end{array}$

$\begin{array}{lllll}120 & 3.53 & 1.17 & 16 & P\end{array}$

$21 \quad P$

$22 \mathrm{P}$

$\begin{array}{lllll}120 & 2.39 & 1.17 & 47 & \text { NP } \\ 120 & 2.37 & 1.03 & 48 & \text { NP } \\ 120 & 2.31 & 1.00 & 49 & \text { NP } \\ 120 & 2.30 & 1.25 & 50 & \text { NP } \\ 120 & 2.23 & 0.99 & 51 & \text { NP } \\ 120 & 2.14 & 1.12 & 52 & \text { NP } \\ 120 & 2.02 & 1.12 & 53 & \text { NP }\end{array}$

HP, highly prevalent; P, prevalent; NP, not prevalent; C, Contractors' unethical tendering practices; E, Tendering practices by clients or consultants at tender evaluation and award stage; T, Tendering practices by clients or consultants at invitation to tender stage; N, Number; Pi, Prevalence index; SD, Standard deviation. 
TABLE 7: Mann-Whitney $U$ test of differences in the opinions of respondents.

\begin{tabular}{|c|c|c|c|c|}
\hline$S / N$ & Hypothesis tested & Mann-Whitney U & Significance & Inference \\
\hline 1. & $\begin{array}{l}\text { The responses on contractors' unethical tendering practices are similar across the federal and state } \\
\text { levels. }\end{array}$ & 90.5 & 0.361 & Accept the $H_{01}$ hypothesis \\
\hline 2. & $\begin{array}{l}\text { The responses on clients' or consultants' unethical tendering practices at the tender invitation stage } \\
\text { are similar across the federal and state levels. }\end{array}$ & 283.5 & 0.926 & Accept the $H_{\mathrm{o} 2}$ hypothesis \\
\hline 3. & $\begin{array}{l}\text { The responses on the clients' or consultants' unethical tendering practices at the tender evaluation } \\
\text { and award stages are similar across the federal and state levels. }\end{array}$ & 94.5 & 0.872 & Accept the $H_{03}$ hypothesis \\
\hline 4. & $\begin{array}{l}\text { The responses on clients' or consultants' unethical tendering practices are similar at the invitation } \\
\text { to tender and the tender evaluation and award stages. }\end{array}$ & 145 & 0.486 & Accept the $H_{o 4}$ hypothesis \\
\hline
\end{tabular}

$\mathrm{S} / \mathrm{N}$, Serial number.

Indicatively, the contractors studied eschewed collusive tendering, which may have been a result of lack of trust among them. This is reinforced by the low ranks of C11, C12 and C14.

\section{Unethical tendering practices of clients or consultants at the invitation to tender stage}

In Table 4, T1 was ranked the first by the federal and state respondents, and consequently it retained the rank when all the variables were combined and ranked for this group $\left(P_{\text {ia }}=3.91, P_{\text {if }}=3.94\right.$ and $\left.P_{\text {is }}=3.89\right)$. This indicates that bid opening is frequently delayed, thereby creating a period of uncertainty during tendering. In Table 4, T24 ranked the lowest, showing that bids are not secretly submitted on nonworking days. Besides competing on time and cost, prequalified bidders also compete on the ability to submit a competitive tender within the time allowed for tender submission. Bidders who fail to meet the deadline may attempt to 'smuggle' in their bids on non-work days. The low rank of T24 $\left(P_{\mathrm{ia}}=2.02, P_{\text {if }}=2.15, P_{\text {is }}=1.93\right.$ and $\left.P_{\mathrm{i}}=2.02\right)$ means that this unethical practice is not prevalent in the study area.

\section{Unethical tendering practices of clients or consultants at the tender evaluation and award stage}

In Table 5, E1 was ranked first by the state respondents $\left(P_{\text {is }}=4.05\right)$, but it was ranked third by the federal respondents $\left(P_{\text {if }}=3.72\right)$. It is suspected that interference of chief executives at the tender evaluation and award stages is more prevalent at the state level. With the PPA 2007 applicable at the federal level, chief executives of MDAs at that level have become cautious in intervening in the tender evaluation process. Possibly, in Akwa Ibom State, which does not have its own procurement law, the influence of chief executives in the tender evaluation process persists.

E14 ranks the lowest $\left(P_{\mathrm{ia}}=2.48, P_{\mathrm{if}}=2.55\right.$ and $\left.P_{\text {is }}=2.42\right)$. This finding means that tenderers whose bids were not read out during bid opening for whatever reasons automatically stand disqualified from further participation in the tendering process. It is also noticeable that E13 ranked the next to lowest $\left(P_{\text {ia }}=2.53, P_{\text {if }}=2.34\right.$ and $\left.P_{\text {is }}=2.64\right)$. Seemingly, there has been a reduction in instances of awarding contracts without following due process. When all the unethical tendering processes were combined (Table 6), however, it was observed that E13 is still a prevalent unethical tendering practice in the study area $\left(P_{\mathrm{i}}=2.53\right.$, rank $\left.=42 \mathrm{nd}\right)$. This requires further research examination. In spite of this, given that its $\mathrm{P}_{\text {is }} \geq \mathrm{P}_{\text {if }}$, it is suspected that this practice exists more at the state levels, especially, in states that have, which has no dedicated procurement law.

\section{Test of differences in the responses}

A Mann-Whitney $U$ test was carried out to determine whether a significant difference exists between the opinions of the federal and state respondents. From Table 7, it can be inferred that there is no statistically significant difference between the opinions of the federal and state respondents ( $U=90.5, p=0.361)$ with regards to contractors' unethical tendering practices. Similar tests of differences as shown in Table 7 support the inference that, irrespective of the apparent differing rankings by the state and federal government respondents, opinions about unethical tendering practices do not vary significantly in the different stages of tendering and across the two levels of government.

Given this scenario, the responses were all combined to obtain the prevalence index for each of the variables. Table 6 shows that $14(26.42 \%)$ of the variables are highly prevalent in the study area, while $28(52.83 \%)$ are prevalent and 11 $(20.75 \%)$ are not prevalent.

\section{Discussion}

While $44 \%$ of the respondents in Vee and Skitmore's survey had witnessed some forms of collusive tendering, this study's results show that collusive behaviour is not rampant in the study area. C12, C13, C14 and C15, which are related to collusive tendering, were found not to be prevalent. ZarkadaFraser and Skitmore (1998:2) defined collusive tendering as 'an explicit agreement between (competitors) either not to tender, or to tender in such a manner as not to be competitive with one of the other tenderers'. This result is similar to the finding of Abdul-Rahman et al. (2010) that out of 11 unethical practices, collusive tendering ranked $7 \mathrm{th}$. Collusive tendering requires some form of trust or agreement among the tenderers in order to succeed. Apparently, Nigerian contractors are not able to achieve such an agreement at the tendering stage. As a result, Zarkada-Fraser and Skitmore's (1998) conclusion that collusion is an endemic malaise of construction tendering does not hold in this study. The findings of Vee and Skitmore (2003) and Bowen et al. (2007a) that contractors are the most corrupt during tendering are supported by this study because the three most highly prevalent unethical tendering practices (C1, C2 and C3) are all contractor-related. Alutu (2007), Abdul-Rahman et al. (2010) and Wells (2013) noted that bribery and fraud are among the five topmost unethical 
practices in the construction industry. This study supports this position because $\mathrm{C} 1$ (competitors offer bribes to gain access to confidential tendering information) is the highest ranking (most highly prevalent) form of unethical tendering practice. Bowen et al.'s (2007a) and Wells' (2013) observations that the primary form of fraud by contractors is deceit and misinformation is consistent with the ranking of competitors overstating their capacity, experience and qualifications to secure construction contracts (C2) as the second highly prevalent variable in this study. Shan et al. (2016) equally ranked misrepresentation of qualifying documents as the highest collusive tendering practice of Chinese contractors. Just like their Chinese counterparts (Shan et al. 2016), Nigerian contractors are usually required to submit prequalifying documents before being allowed to tender for public sector projects. Normally, the requirements include the resume of qualified personnel, list of equipment owned and proofs of successful execution of similar projects. It is possible that they often falsify these documents in the bid to be allowed a chance to participate in the tendering process.

This study reveals that despite the existence of procurement laws and regulations, unethical tendering practices still thrive in the Nigerian construction industry. It is possible that procurement officers and contractors consider the benefits of unethical practices during tendering as outweighing its legal consequences. This corroborates Mason's (2009) observation that:

Those engaged in criminal acts are aware of the consequences and often consciously choose to run the risks involved. The existence of an ethical code is unlikely to make a difference to those instances of unethical behaviour. (p. 204)

Vee and Skitmore (2003) and Oladinrin and Ho (2014) equally observed that codes alone are insufficient to enshrine ethical conduct. There is also the likelihood that most contractors and public procurement officers or consultants are ignorant of the extant procurement laws. In Nigeria's case, this study points to the inability of procurement laws to enshrine ethical conducts at the tendering stage of public procurement, either because of the procuring officers' ignorance, outright disregard or ineffective enforcement of the procurement laws.

The results of this study further show that bid opening is unjustifiably delayed after the submission of tenders. This contravenes section 89 of the PPGWR 2007, which provides that:

The date, hour and place for the receipt of bids and for the bid opening shall be announced in the invitation to tender. The time for bid opening shall be the same as for the deadline for the receipt of bids or, if bids are received in a location different from the place of bid opening, promptly thereafter, allowing just sufficient time to take the bids to the place announced for bid opening. (p. 607)

Section 29(c) of the Edo State Public Procurement Law 2012 stipulates that the procuring entity shall:

ensure that the bid opening takes place immediately following the deadline stipulated for the submission of bids or any extension. (p. 20)
Nevertheless, in states that have no procurement laws, procuring entities may delay the opening of tenders after the deadline for submission because they are not compelled by any laws to act promptly on the tenders.

This study reveals unethical intervention of chief executives of public procuring entities in the tendering processes, particularly at the tender evaluation and award stage. In a previous study, Familoye, Ogunsemi and Awodele (2015) similarly found that among the significant challenges facing the implementation of the PPA 2007 is the intervention of chief executives of procuring entities in the tendering processes. Le et al. (2014) also noted that the chief executives engage in corruption themselves which is a negative leader role that encourages the spread of unethical practices within an organisation. Section 33(3) of the PPA 2007 places the responsibility of bid evaluation in the hands of the Tenders Board of Procuring Entities, while section 32(a) of the PPGWR 2007 makes the chief executives of procuring entities the chairmen of the procuring entities' tender boards. These chief executives become the prime target of contractor's bribes as a result. When such bribes are received by the chief executives, they move to justify the bribes by intervening in the evaluation of tenders to ensure that the bribing contractor emerges as the winner.

There is no significant difference between the unethical tendering practices at the federal and state public sector levels. For this study, the tendering ethical culture at national and subnational levels do not differ despite differing procurement laws at these levels.

\section{Conclusions}

This study investigated unethical tendering practices in public sector project procurement against the backdrop of the recent institutional and statutory changes in Nigeria. It was observed that the existence of procurement laws and guidelines notwithstanding, unethical tendering practices still occur in the Nigerian public sector. No statistically significant difference was found between the unethical tendering practices at the federal and state levels of public sector procurement. Likewise, the difference between unethical tendering practices at the invitation to tender and tender evaluation and award stages is not statistically significant. Ethical tendering culture within the country does not differ, hence relativism is inapplicable in explaining the ethical conduct of participants in a tendering process within the country.

Unethical contractor-related tendering practices ranked first to third highest among the unethical tendering practices. This underscores the need for the Nigerian government to educate contractors on the ways to win contracts without necessarily offering bribes in any form. The finding of this study that contractors overstate their capacity, experience and qualifications to secure construction contracts reflects the dearth of quality manpower, low financial capacity and lack of equipment associated with the contractors, most of whom are indigenous firms. This shows that the fight against 
tendering corruption must include a deliberate attempt to boost the capacities of contractors.

This study found that chief executives of procuring entities intervene at the tender evaluation and award stage and help their preferred contractors to win contracts. Given this outcome, it is recommended that chief executives of public procuring entities should not be the chairs of their organisations' tender boards. Rather, they should be ordinary members of the boards. Reputable members of professional bodies can be given the roles of chairing public sector tender boards' meetings. Such chairs, knowing that they represent a constituency of professionals, will more likely uphold tendering ethics.

Further studies should be carried out to reveal whether unethical tendering practices in states with procurement laws are significantly different from those in the states without such laws. It will also serve the interest of practitioners to know the differences, if any, in the procurement laws applicable in the different states of Nigeria.

\section{Acknowledgements}

The authors are grateful to the public and private sector organisations that provided them with information or data used in this study.

\section{Competing interests}

The authors declare that they have no financial or personal relationships that may have inappropriately influenced them in writing this article.

\section{Authors' contributions}

C.P.O. did most of the writing and analysis. C.F.A. reviewed previous studies, thus setting an agenda for the current study.

\section{References}

Abdul-Rahman, H., Wang, C. \& Yap, X.W., 2010, 'How professional ethics impact construction quality: Perception and evidence in a fast developing economy', construction quality: Perception and evidence
Scientific Research and Essays 5(23), 3742-3749.

Adeyinka, B.A., Jagboro, G.O., Ojo, G.K. \& Odediran, S.J., 2013, 'Level of compliance of core construction professionals to ethical standards in Nigeria', Journal of Construction Project Management and Innovation 3(2), 640-659.

Adnan, H., Hashim, N., Mohd, N. \& Ahmad, N., 2012, 'Ethical issues in the construction industry: Contractor's perspective', Procedia-Social and Behavioural Sciences 35 719-727. https://doi.org/10.1016/j.sbspro.2012.02.142

Aduda, G.T., 2007, 'Budget Monitoring and Price Intelligence Unit (Due Process): A mechanism of combating corruption in Infrastructure delivery in Nigeria', in $M$. Sohail (ed.), Partnering to combat corruption, pp. 1-52, Water Engineering and Development Centre, Leicestershire.

Agbor, D., 2012, Public procurement (Nigeria), Lex Mundi Ltd., Lagos.

Aigbavboa, C., Oke, A. \& Tyali, S., 2016, 'Unethical practices in South-African construction industry', in F. Emuze (ed.), 5th Construction Management Conference, Port Elizabeth, South Africa, November 28-29, Department of Construction Management, Port Elizabeth, pp. 15-22.

Al-sweity, A.Y., 2013, 'Unethical conduct among professionals in construction industry', Master's Degree thesis in the Islamic University of Gaza, viewed 25 May 2017, from http://library.iugaza.edu.ps/thesis/109852.pdf

Alutu, O.E., 2007, 'Unethical practices in Nigerian construction industry: Prospective engineers' viewpoint', Journal of Professional Issues in Engineering Education and Practice 133(2), 84-88. https://doi.org/10.1061/(ASCE)1052-3928(2007)133:2(84)

Ameh, O.J. \& Odusami, K.T., 2010a, 'Professionals' ambivalence toward ethics in the Nigerian construction industry', Journal of Professional Issues in Engineering Education and Practice 136(1), 9-16. https://doi.org/10.1061/(ASCE)1052-3928 (2010)136:1(9)
Ameh, O.J. \& Odusami, K.T., 2010b, 'Nigerian building professionals' ethical ideology and perceived ethical judgement', Australasian Journal of Construction Economics and Building 10(3), 1-13. https://doi.org/10.5130/ajceb.v10i3.1602

Ameyaw, E.E., Pärn, E., Chan, A.P., Owusu-Manu, D.G., Edwards, D.J. \& Darko, A., 2017 'Corrupt practices in the construction industry: Survey of Ghanaian experience', Journal of Management in Engineering 33(6), 05017006. https://doi.org/10.1061/ (ASCE)ME.1943-5479.0000555

Aniekwu, A.N., Anthony, C.I. \& Kehinde, O.M., 2015, 'Critical issues in reforming the Nigerian construction industry', British Journal of Applied Science \& Technology 5(3), 321-332. https://doi.org/10.9734/BJAST/2015/12617

Armstrong, J.S. \& Overton, T.S., 1977, 'Estimating nonresponse bias in mail surveys', Journal of Marketing Research 14(3), 396-402. https://doi.org/10.2307/3150783

Azher, S., Selph, J. \& Maqsood, T., 2011, 'Unethical business practices and corruption in international construction: A survey of American contractors working overseas', in K. Haugbølle, S. Gottlieb \& K.E. Kähkönen, O.J. Klakegg, G.A. Lindahl \& K. Widén (eds.), 6th Nordic Conference on Construction Economics and Organisation Shaping the Construction/Society Nexus Volume 3: Construction in Society, 13-15 April 2011 Danish Society of Engineers Conference Centre, Copenhagen, Denmark, Danish Building Research Institute, Aalborg University, Hørsholm, pp. 457-467.

Bayles, M.D., 1989, Professional ethics, 2nd edn., Belmont Publishing Company, Santa Ana, CA.

Bowen, P., Akintoye, A., Pearl, R. \& Edwards, P.J., 2007a, 'Ethical behaviour in the South African construction industry', Construction Management and Economics 25(6), 631-648. https://doi.org/10.1080/01446190701225707

Bowen, P., Pearl, R. \& Akintoye, A., 2007b, 'Professional ethics in the South African construction industry', Building Research and Information 35(2), 189-205. https://doi.org/10.1080/09613210600980267

Bowen, P.A., Edwards, P.J. \& Cattell, K., 2012, 'Corruption in the South African construction industry: A thematic analysis of verbatim comments from survey participants', Construction Management and Economics 30(10), 885-901. https:// participants', Construction Management
doi.org/10.1080/01446193.2012.711909

Chartered Institute of Building (CIOB), 2013, Corruption in the UK construction industry, $\mathrm{CIOB}$, London.

Chinyio, E., 2011, 'The cost of tendering', in Toole T.M. (ed.), Engineering project organisations conference, viewed $\mathrm{n} . \mathrm{d}$. from http://www.academiceventplanner. com/EPOC2011/papers/chinyio.pdf

DeCew, J.W., 1990, 'Moral conflicts and ethical relativism', Ethics 101(1), 27-41. https://doi.org/10.1086/293258

Dodd-McCue, D. \& Tartaglia, A., 2010, 'Self-report response bias: Learning how to live with its diagnosis in chaplaincy research', Chaplaincy Today 26(1), 2-8. https:// doi.org/10.1080/10999183.2010.10767394

England, J.M., 2011, 'Can a single code for professionals promote ethical improvement in the construction industry?', FIG Working Week 2011, Bridging the Gap between Cultures Marrakech, Morocco, 18th-22nd May.

Familoye, O., Ogunsemi, D.R. \& Awodele, O.A., 2015, 'Assessment of the challenges facing the effective operations of the Nigerian Public Procurement Act 2007', International Journal of Economics, Commerce and Management 3(20), 957-968.

Federal Republic of Nigeria (FRN), 2007a, Public Procurement Act, 2007, Federal Government Printer, Lagos.

Federal Republic of Nigeria (FRN), 2007b, Public Procurement Regulations for Goods and Works, 2007, Federal Government Printer, Lagos.

Gael, M., 2010, 'Ethical relativism vs absolutism: Research implications', European Business Review 22(4), 446-464. https://doi.org/10.1108/09555341011056203

Gentry, J., 1990, An investigation into fraud and unethical conduct in the construction industry, viewed 18 July 2017, from http://www.dtic.mil/dtic/tr/fulltext/u2/ a240756.pdf

Gliem, J.A. \& Gliem, R.R., 2003, 'Calculating, interpreting, and reporting Cronbach's Alpha Reliability Coefficient for Likert-Type Scale', in 2003 Midwest Research to Practice Conference in Adult, Continuing, and Community Education, viewed 10 June 2017, from http://www.ssnpstudents.com/wp/wp-content/uploads/2015/02/ Gliem-Gliem.pdf

Gordon, R.A., 1987, 'Social desirability bias: A demonstration and technique for its reduction', Teaching of Psychology 14(1), 40-42. https://doi.org/10.1207/ s15328023top1401_11

Greene, J.C., Caracelli, V.J. \& Graham, W.F., 1989, 'Toward a conceptual framework for mixed-method evaluation designs', Educational Evaluation and Policy Analysis 11(3), 225-274. https://doi.org/10.3102/01623737011003255

Jibrin, M.S., Ejura, S.B. \& Nwaorgu, A.I., 2014, 'The public procurement reforms in Nigeria: Implementation and compliance challenges', Journal of Asian Business Strategy 4(11), 149.

King, M.F. \& Bruner, G.C., 2000, 'Social desirability bias: A neglected aspect of validity testing', Psychology and Marketing 17(2), 79-103. https://doi.org/10.1002/ (SICI)1520-6793(200002)17:2\%3C79::AID-MAR2\%3E3.0.CO;2-0

Kline, P., 1999, The handbook of psychological testing, 2nd edn., Routledge, London.

Le, Y., Shan, M., Chan, A.P.C. \& Hu, Y., 2014, 'Investigating the causal relationships between causes of and vulnerabilities to corruption in the Chinese public construction sector', Journal of Construction Engineering and Management 140(19), 1-12. https://doi.org/10.1061/(ASCE)CO.1943-7862.0000886

Lyons, D., 1976, 'Ethical relativism and the problem of incoherence', Ethics 86(2), 107-121. https://doi.org/10.1086/291985

Mason, J., 2009, 'Ethics in the construction industry: The prospects for a single professional code', International Journal of Law in the Built Environment 1(3), 194-205, viewed 15 June 2017, from http://eprints.uwe.ac.uk/11551 
National Bureau of Statistics (NBS), 2016a, Job creation survey, 2nd and 3rd quarters 2016 summary findings and selected tables, viewed 18 July 2017, from file:///C:/ 2016 summary findings and selected tables, viewed 18 July 2017, from file:///C:/ Users/Quantity\%20Survey/Downloads

National Bureau of Statistics (NBS), 2016b, Nigerian gross domestic product report, quarter one 2016, viewed 10 October 2017, from file:///C:/Users/Quantity\%20 Survey/Downloads/GDP\%20Q1\%202016\%20ICl\%20Merged\%20finalvs2\%20(6).pdf

Ofori, G., 2000, 'Challenges of construction industries in developing countries: Lessons from various countries', in 2nd International Conference on Construction in Developing Countries: Challenges Facing the Construction Industry in Developing Countries, Gaborone, November, pp. 15-17.

Ofori, G., 2007, 'Construction in developing countries', Construction Management and Economics 25(1), 1-6. https://doi.org/10.1080/01446190601114134

Oladinrin, O.T. \& Ho, M.F.C., 2014, 'Strategies for improving codes of ethics implementation in construction organisations', Project Management Journa 45(5), 15-26. https://doi.org/10.1002/pmj.21444

Oliver, J., London, K. \& Everingham, P., 2006, 'Ethical behaviour in the construction procurement process', in K. London (ed.), Industry and business development report No. 2002-62-A, pp. 1-64, Cooperative Research Centre for Construction Innovation, Brisbane.

Omodunbi, B.A., Odiase, P.O., Olaniyan, O.M. \& Esan, A.O., 2016, 'Cybercrimes in Nigeria: Analysis, detection and prevention', Journal of Engineering and Technology 1(1), 37-42.

Onuigbo, R.A. \& Eme, O.I., 2015, 'Corruption \& administration in Nigeria: The character of the state thesis', Arabian Journal of Business and Management Review (Nigerian Chapter) 3(9), 17-36. https://doi.org/10.12816/0017679

Organisation for Economic Co-operation and Development (OECD), 2014, OECD foreign bribery report: An analysis of the crime of bribery of foreign public officials, viewed 18 July 2017, from https://doi.org/10.1787/9789264226616-en

Public Procurement Regulations for Goods and Works (PPRGW), 2007, viewed 20 August, 2017 from http://www.bpp.gov.ng/index.php?option=com joomdoc\&view=docume nts\&path=PUBLIC\%2OPROCUREMENT\%20DOCUMENTS/Public\%20Procurement\%20 Goods\%20And\%20Works\%20Regulations\%202007.docx\&ltemid=720

Rahman, H.A., Karim, S.B.A., Danuri, M.S.M., Berawi, M.A. \& Yap, X.W., 2007, 'Does professional ethic affect construction quality?', in Quantity Surveying International Conference, Kuala Lumpur, Malaysia, September 4-5, viewed 05 April 2017, from http://www.academicjournals.org/article/article1380540892_Abdul-Rahman\%20 et\%20al.pdf

Ray, R.S., Hornibrook, J.F. \& Skitmore, M.R., 1999, 'Ethics in tendering: A survey of Australian opinion and practice', Construction Management and Economics 17(2) 139-153. https://doi.org/10.1080/014461999371646
Shakantu, W., 2006, 'Corruption in the construction industry; Forms susceptibility and possible solutions', Civil Engineering 14(7), 43-47, viewed 07 August 2017, from https://journals.co.za/content/civeng/14/7/EJC25511

Shan, M., Chan, A.P., Le, Y., Hu, Y. \& Xia, B., 2016, 'Understanding collusive practices in Chinese construction projects', Journal of Professional Issues in Engineering Education and Practice 143(3), 05016012. https://doi.org/10.1061/(ASCE)El.19435541.0000314

Somers, M.J., 2001, 'Ethical codes of conduct and organisational context: A study of the relationship between codes of conduct, employee behaviour and organisational values', Journal of Business Ethics 30(2), 185-195. https://doi.org/10.1023/ A:1006457810654

Spicer, A., Dunfee, T.W. \& Bailey, W.J., 2004, 'Does national context matter in ethical decision making? An empirical test of integrative social contracts theory', Academy of management Journal 47(4), 610-620. https://doi.org/10.2307/20159605

Suen, H., Cheung, S.O. \& Mondejar, R., 2007, 'Managing ethical behaviour in construction organisations in Asia: How do the teachings of Confucianism, Taoism and Buddhism and globalization influence ethics management?', Internationa Journal of Project Management 25(3), 257-265. https://doi.org/10.1016/j. ijproman.2006.08.001

Transparency International, 2016, Corruption perception index, viewed 26 August 2017, from https://www.transparency.org/research/cpi

Usman, T., 2014, 'Nigerian govt. urges states to replicate procurement laws', Premium Times, 10 November, viewed 26 August 2017, from http://www.premiumtimesng. com/business/170883-nigerian-govt-urges-states-to-replicate-procurement-laws. html

Vee, C. \& Skitmore, R.M., 2003, 'Professional ethics in the construction industry', Engineering Construction and Architectural Management 10(2), 117-127. https:// doi.org/10.1108/09699980310466596

Wells, J., 2013, 'Corruption and collusion in construction: A view from the industry', in T. Søreide \& A. Williams (eds.), Corruption, grabbing and development real world challenges, pp. 23-33, Edward Elgar Publishing Limited, Cheltenham. https://doi. org $/ 10.4337 / 9781782544418$

Zarkada-Fraser, A. \& Skitmore, M.R., 1998, 'A classification of factors influencing participation in collusive tendering agreements', in Proceedings Theory Development and Models of Ethical Decision-Making track, Ethical and Societal Issues Conference, American Marketing Association (AMA) Marketing Exchange Colloquium, Vienna Hilton, Austria, viewed 15 January 2017, from https://eprints. qut.edu.au/4545/1/4545.pdf

Zhang, B.L., Yun, X.B. \& Skitmore, M., 2017, 'Causes of business-to-government corruption in the tendering process in China', Journal of Management in Engineering 33(2), 05016022. https://doi.org/10.1061/(ASCE)ME.1943-5479.0000479 